Open Access

Research Article
Res. Agric. Livest. Fish.

Vol. 2, No. 2, August 2015: 301-306

\title{
EFFECT OF DIFFERENT REARING SYSTEMS ON THE GROWTH AND SURVIVAL OF GOLD FISH (Carassius auratus)
}

\author{
Rabeya Rahmatullah*, Md. Ariful Islam and Shah Mohammad Rahmatullah \\ Department of Aquaculture, Faculty of Fisheries, Bangladesh Agricultural University, \\ Mymensingh-2202, Bangladesh \\ *Corresponding author: Rabeya Rahmatullah, E-mail: tori.baufiish@yahoo.com
}

\section{ARTICLE INFO ABSTRACT}

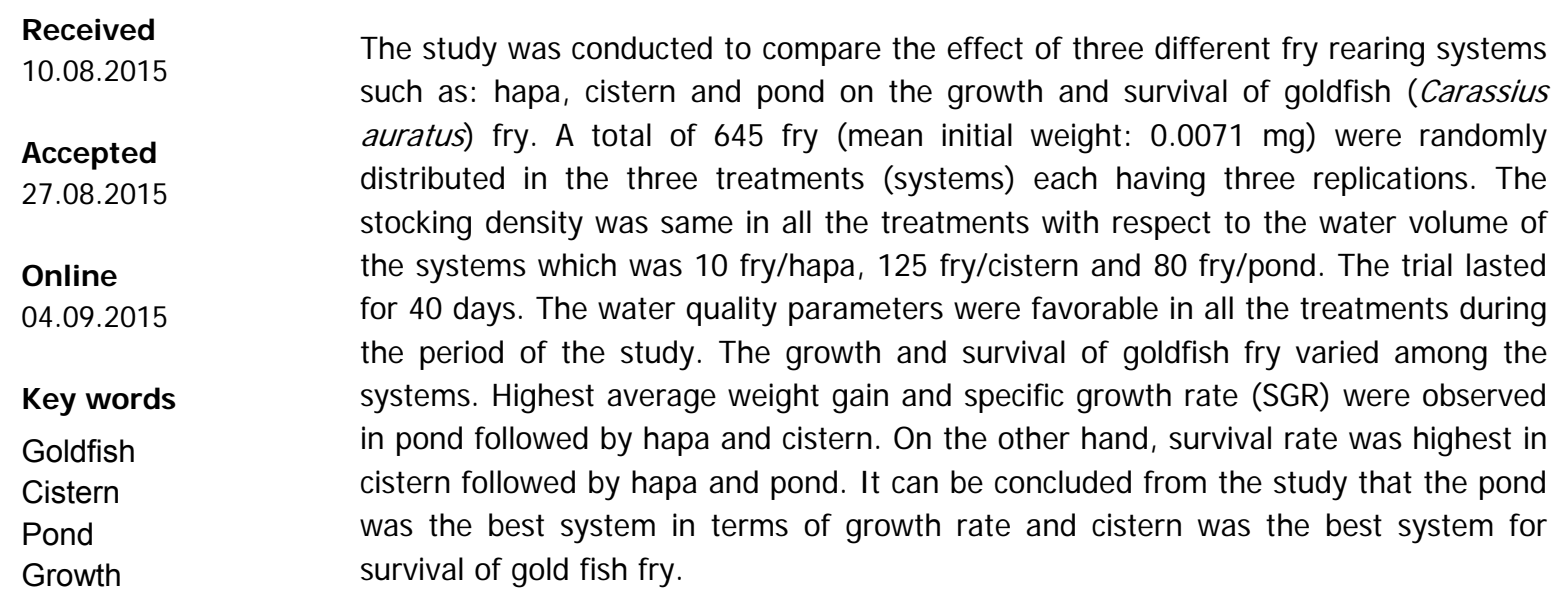

Survival

To cite this article: R Rahmatullah, MA Islam and SM Rahmatullah, 2015. Effect of different rearing systems on the growth and survival of gold fish (Carassius auratus). Res. Agric. Livest. Fish. 2 (2): 301-306. 


\section{INTRODUCTION}

Gold fish is the most popular ornamental fish used in Bangladesh. There are very few established hatcheries in the country where breeding of gold fish is performed. Breeding is mainly carried out in small scale. There is no available scientific information on the rearing of goldfish fry in Bangladesh. Mainly adult fish are preferred for keeping in aquarium for aesthetic purposes. The rearing of fry to adult stage may be critical both from biological and economic point of view. Fry may be reared in a wide variety of systems ranging from jars to ponds. The point to be considered is which system is more suitable. If fry are reared in jars or aquarium it may be expensive because cost will be incurred in the development of such system. Moreover they will have to be used with utmost care otherwise they will not last for long. Systems which are mainly used for the rearing of food fish fry may be used for fry rearing of gold fish. Most commonly used systems for fry rearing are ponds, hapas, and cisterns. Growth and survivability of fry vary among the systems. This is mainly due to differences in water quality parameters and availability of natural food. If maintained properly, these systems may be suitable for gold fish fry rearing. The study was carried out to compare the effects of different rearing systems on the growth and survival of gold fish fry.

\section{MATERIALS AND METHODS}

The experiment was conducted in the Department of Aquaculture, Faculty of Fisheries, Bangladesh Agricultural University, Mymensingh for a period of 40 days. In the experiment the growth and survival rate of Carassius auratus fry under different systems (hapa, cistern, pond) were assessed.

\section{Experimental fry}

Fourteen days old fry of Carassius auratus were used in this experiment. The fry had an initial average total length of $6.0 \mathrm{~mm}$ and weight of $0.0071 \mathrm{~g}$.

\section{System dimension}

The experiment was conducted in 3 hapas, 3 cisterns and 3 small ponds. The size of each hapa was 75 $\mathrm{cm} \times 60 \mathrm{~cm} \times 60 \mathrm{~cm}$, the size of each cistern was $210 \mathrm{~cm} \times 180 \mathrm{~cm} \times 90 \mathrm{~cm}$ and the size of each was pond $240 \mathrm{~cm} \times 210 \mathrm{~cm} \times 45 \mathrm{~cm}$. The hapas were set in cisterns.

\section{Preparation of the systems}

The cisterns located behind the faculty of fisheries were properly cleaned and then sun dried for a day and filled with clean groundwater. The fine meshed hapa were set in different cisterns. Three newly dug ponds were limed at the rate of $1 \mathrm{~kg} / \mathrm{decimal}$. After 3 days these ponds were filled with clean groundwater and were fertilized by urea and TSP at the rate of $200 \mathrm{gm} /$ decimal. All the systems were covered by nylon net to protect the fish from birds and other predators. One week after the preparation of the systems the 14 days old fry were stocked.

\section{Experimental protocol}

The hapa, cistern and pond systems were designated as $T_{1}, T_{2}$ and $T_{3}$ respectively. Each treatment had three replications: $H_{1}, H_{2}, H_{3}$ for $T_{1} ; C_{1}, C_{2}, C_{3}$ for $T_{2}$ and $P_{1}, P_{2}, P_{3}$ for $T_{3}$. The stocking densities in $T_{1}, T_{2}$ and $\mathrm{T}_{3}$ were $10 \mathrm{fry} / \mathrm{hapa}, 125$ fry/cistern and 80 fry/pond.

\section{Feed supply}

Commercial feed named 'Mega feed' which had an approximate protein content of $34 \%$ was selected for the experiment. The fry were fed up to the satiation 3 times daily at 9:30 am, 1:00 pm and 4:00 pm. The powdered artificial feed was spread homogenously on the water surface of the systems (hapa, cistern, and pond). The fry were considered satiated when they stopped searching for food in about 30 minutes of food supply. 


\section{Sampling of fish}

Fish were sampled at 10 days interval. Ten fry were caught from each system by a hand scoop net, their lengths $(\mathrm{mm})$ were measured by meter scale and weights $(\mathrm{mg})$ were recorded by electronic balance.

\section{Water quality parameters}

\section{Water temperature, $\mathrm{pH}$ and Dissolved oxygen (mg/l)}

Water temperature $\left({ }^{\circ} \mathrm{C}\right)$ from each system was recorded by an alcohol thermometer, $\mathrm{pH}$ was measured by a digital pH meter (Jenway, Model 3020) and Dissolved oxygen was measured by a digital Dissolved Oxygen meter (YSI MODEL 58).

\section{Nitrite}

Nitrite was measured by nitrite testing kit. The procedure was as follows:

- The measurement vial was rinsed several times with the water to be tested and filled to the $5 \mathrm{ml}$ mark. The vial was dried on the outside.

- $\mathbf{5}$ drops of reagent 1 and 2 was added each.

- The vial was shook until the liquid was evenly distributed.

- The colors were compared after five minutes. The vial was placed on the color chart and the colors were compared from a position above under natural daylight. Direct sunlight was avoided.

\section{Ammonium (mg/l)}

Ammonium was measured by ammonium testing kits. The procedures were as follows:

- The measurement vial was rinsed several times with the water to be tested and filled to the $10 \mathrm{ml}$ mark. The vial was dried on the outside.

- Six drops of reagent 1 were added and shook until the liquid was evenly distributed.

- Six drops of reagent 2 were added and shook in the same manner.

- Six drops of reagent 3 were added and shook in the same manner.

- $\quad$ The color was compared after 5 minutes. Then the vial was placed on the chart and the color was compared from a position above under natural day light. Direct sunlight was avoided.

\section{Alkalinity}

Alkalinity was measured by alkalinity testing kit. The procedure was as follows:

- The test vessel was rinsed several times with the water to be tested and filled to $5 \mathrm{ml}$ mark.

- One drop of indicator B+M was added and swirled. The solution turned greenish-blue.

- Titrant solution was added drop wise and the drops were counted. The solution was mixed slowly until the color changed to lavender-gray.

- One more drop was added and the solution turned orange. The number of drops used was counted and multiplied by 17 to obtain result in milligram per liter of calcium carbonate.

\section{Growth and survival parameters of fish}

\section{Weight gain (g)}

Weight gain $(\mathrm{g})=$ Mean final weight $(\mathrm{g})-$ Mean initial weight $(\mathrm{g})$

\section{Specific growth rate (\% per day)}

rate $(S G R)=-\log _{\mathrm{e}} \mathrm{W}_{2}-\log _{\mathrm{e}} \mathrm{W}_{1}$
Where
$\mathrm{W}_{1}=$ the initial live body weight $(\mathrm{g})$ at time $\mathrm{T}_{1}$ (day)
$\mathrm{W}_{2}=$ the final live body weight $(\mathrm{g})$ at time $\mathrm{T}_{2}$ (day)


Survival rate (\%)

The survival rate of each treatment was calculated by counting each species survived at the end of the experiment.

$$
\text { Survival rate }(\%)=\frac{\text { No. of fish harvested }}{\text { No. of fish stocked }}
$$

\section{Statistical analysis}

Data were compiled into means \pm SD to check normality of the data for the determination of the effects of growth and survival profile of the gold fish (Carassius auratus) fry in different systems (hapa, cistern and pond). The level of significance was taken as $P \leq 0.05$.

\section{RESULTS AND DISCUSSION}

\section{Water quality parameters}

The results of the water quality parameters such as temperature $\left({ }^{\circ} \mathrm{C}\right), \mathrm{pH}$, dissolved oxygen $(\mathrm{mg} / \mathrm{L})$, nitrite ( $\mathrm{mg} / \mathrm{L})$, ammonium $(\mathrm{mg} / \mathrm{L})$ and alkalinity $(\mathrm{mg} / \mathrm{L})$ during the experimental period are presented in Table 1.

Temperature recorded during the experimental period was more or less similar in different treatments and varied from 24 to $30^{\circ} \mathrm{C}$. The highest temperature $\left(29^{\circ} \mathrm{C}\right)$ was recorded in treatment $T_{1}, T_{2}$ and $T_{3}$ in October was due to high intensity of sunlight and the lowest temperature $\left(26^{\circ} \mathrm{C}\right)$ was recorded in systems in November which might be due to low intensity of sunlight and cool air flow. Azim et al. (1995) recorded mean values of temperature $26^{\circ} \mathrm{C}$ from a set of ponds and he observed this data is very significant for the production of young fish fry. The $\mathrm{pH}$ range in the experimental period was found to vary from 7.40 to 8.25 . Most natural water has $\mathrm{pH}$ values of 6.5 to 9 (Boyd, 1982). The present finding was within acceptable range required for fish culture 6.5 to 8.5 as suggested by DoF, 1996. In the present study the dissolved oxygen content in water ranged from 5.11 to $6.42 \mathrm{mg} / \mathrm{l}$. Uddin (2002) measured dissolved oxygen to range from 2.2 to $8.8 \mathrm{mg} / \mathrm{l}$ which is similar to the present study.

Table 1. Water quality parameters under different treatments during the study period.

\begin{tabular}{lllllll}
\hline Treatment & $\begin{array}{l}\text { Water } \\
\text { temperature } \\
\left({ }^{\circ} \mathrm{C}\right)\end{array}$ & $\mathbf{p H}$ & $\begin{array}{l}\text { Dissolved } \\
\text { oxygen } \\
(\mathbf{m g} / \mathrm{L})\end{array}$ & $\begin{array}{l}\text { Nitrite } \\
(\mathbf{m g} / \mathrm{L})\end{array}$ & $\begin{array}{l}\text { Ammonium } \\
(\mathbf{m g} / \mathrm{L})\end{array}$ & $\begin{array}{l}\text { Alkalinity } \\
(\mathrm{mg} / \mathrm{L})\end{array}$ \\
\hline $\mathrm{T}_{1}$ & $27.26 \pm 1.41$ & $7.69 \pm 0.30$ & $6.22 \pm 1.35$ & $0.01-0.03$ & $0-0.03$ & $195.5 \pm 9.81$ \\
\hline $\mathrm{T}_{2}$ & $27.26 \pm 1.41$ & $7.69 \pm 0.30$ & $6.22 \pm 1.35$ & $0.01-0.03$ & $0-0.03$ & $195.5 \pm 9.81$ \\
\hline $\mathrm{T}_{3}$ & $27.26 \pm 1.41$ & $7.83 \pm 0.29$ & $6.42 \pm 1.53$ & $0.01-0.03$ & $0-0.03$ & $229.5 \pm 9.81$ \\
\hline
\end{tabular}

Nitrite is the highest toxic product of the major inorganic nitrogen compounds. Nitrite is formed primarily as an intermediary in the conversion of ammonia to nitrate, a process known as nitrification. Because it gets converted to the nitrate end product quickly, high nitrite concentrations are not common in aquatic systems. In the present experiment nitrite was found to range from 0.01 to $0.03 \mathrm{mg} / \mathrm{L}$ in all the treatments which is similar to the findings of Raihan (2010).

In the present study ammonium concentration ranged from 0 to $0.03 \mathrm{mg} / \mathrm{L}$ which falls within the limits suggested by Boyd (1998). The findings are also more or less similar to that of Rashid (2008). Alkalinity (mg/l) of the experimental systems varied from 187 to $238 \mathrm{mg} / \mathrm{l}$. Uddin (2002) observed that alkalinity varied from 45 to $180 \mathrm{mg} / \mathrm{l}$ in earthen ponds of field laboratory of Bangladesh Agricultural University, Mymensingh. The values are near to the findings of the present study. 


\section{Growth and survival parameters of gold fish fry}

Weight gain (g), percent weight gain, specific growth rate (\% per day) and survival rate (\%) of gold fish in different treatments are presented in Table 2. Limited data exist on growth parameters of ornamental fish including gold fish, although some information is available for carp species. In the present experiment stocking density was same in all the systems per unit of water volume. The results of this experiment showed that, the highest growth rate was achieved in $T_{3}$. The average weight gain of individual fish in $T_{3}(3.50 \pm 1.11 \mathrm{~g})$ was higher than $T_{1}(2.59 \pm 0.51 \mathrm{~g})$ and $T_{2}(1.23 \pm 0.17 \mathrm{~g})$. Mean weight gain of common carps ranged from 0.76 to $1.12 \mathrm{~g}$ in cages found by Rai and Bista (2000), which is lower than the present study. Prithwiraj et al. (2008) found that the mean weight gain of the koi carps in the earthen pond ranged from $3.14 \mathrm{~g}$ to $9.64 \mathrm{~g}$ and this value is higher than the present study. Higher weight gain of koi carp in pond treatment could be attributed to better water quality in that treatment (Jha \& Barat, 2005).

Table 2. Growth and survival parameters of gold fish (Carassius auratus) fry observed in different treatments during the study period.

\begin{tabular}{lccc}
\hline \multirow{2}{*}{ Parameters } & \multicolumn{3}{c}{ Treatments } \\
\cline { 2 - 4 } & $\mathbf{T}_{\mathbf{1}}$ & $\mathbf{T}_{\mathbf{2}}$ & $\mathrm{T}_{\mathbf{3}}$ \\
\hline Weight gain (g) & $02.59 \pm 0.51$ & $01.23 \pm 0.17$ & $03.50 \pm 1.11$ \\
SGR (\%/day) & $06.39 \pm 0.22$ & $05.60 \pm 0.15$ & $06.68 \pm 0.31$ \\
Survival rate (\%) & $40.00 \pm 26.46$ & $74.93 \pm 9.20$ & $24.17 \pm 8.87$ \\
\hline
\end{tabular}

The highest SGR for the gold fish culture was in $T_{3}$, indicating that this system of culture gives the better growth of fish than other two systems. In this experiment the SGR values were $6.39,5.60,6.68 \%$ per day in $T_{1}, T_{2}$ and $T_{3}$ respectively. Specific growth rates of 5.60 to $6.70 \%$ per day calculated from this investigation were high compared to those published for the gold fish which were between 0.443 to $0.499 \%$ per day (Priestley et al., 2005) and closely related Common Carp (Cyprinus carpio) which were between 2.81-2.92\% per day (Przybyl and Mazurkiewicz, 2004) and $2.6 \%$ per day for the Indian Major Carp (Catla catla) (Murthy and Naik, 2000). These higher growth rates are probably because the gold fish in this study were fed rations to satiation level in order to maximal growth. Additionally, a further explanation for the higher SGR values of these gold fish were related to the good water quality of the culture systems and the food delivered to the fish the whole time of the culture period was very nutritious and were preferable to the fish.

Rema and Gouveia (2005) stated that the high survival and growth rates of goldfish larvae (Carassius auratus) were observed in cistern and he also noted that there were no significant differences in total length and total weight among the fishes in his experiment and the growth of goldfish larvae was independent. In this experiment the survival rate of gold fish (C. auratus) was recorded $40 \%, 74.93 \%$ and $24.17 \%$ in $\mathrm{T}_{1}, \mathrm{~T}_{2}$ and $T_{3}$ respectively at the harvesting time. The highest survival rate was obtained from $T_{2}$ and lowest survival rate obtained from $\mathrm{T}_{3}$. In the whole period of the experiment the water quality of all the systems was really good and that's why the survival rate was satisfactory in the cistern and hapa. However the survival rate was really poor in pond, this may be the because of the pond protection from the predator was not so good compared to hapa and cistern. Priestley (2005) reported that with suitable water quality in cisterns and 4-6 times feeding frequency all the fish remained healthy with no mortalities.

From this experiment we found that the growth rate was very high in pond than other two systems however the survival rate was low in pond. Higher survival rate was obtained from the cistern although in this system the growth was low than other two systems. With the proper management, pond system should be the best system for gold fish fry rearing. 


\section{CONCLUSION}

Ornamental fish rearing has gained much importance now-a-days and gold fish is one of the most favored species. Ornamental fish hatcheries are comparatively low though the breeding techniques are quite easy. If efficient fry rearing techniques are developed it will be possible to meet the local demand of gold fish and will even pave the path of export in the future. The growth and survival of gold fish fry in three different systems: hapa, cistern and pond were observed in the present study. It was found that pond system was best in terms of growth rate while cistern was best for survival rate. Further research is needed in this area to identify the most suitable rearing technique which will be viable both biologically and economically.

\section{COMPETING INTEREST}

The authors declare that they have no competing interests.

\section{REFERENCES}

1. Azim, ME, SS Talukder, MA Wahab, MM Haque and MS Haque, 1995. Effect of liming and maintenance of total hardness level in fish production in fertilized ponds. Progressive Agriculture, 6 : 4-14.

2. Boyd, CE, 1982. Water quality management for pond fish culture. Elsevier Sci. Publ. Co. Amsterdam, Oxford, New York. 318 p.

3. Boyd, CE, 1998. Water quality for pond aquaculture. Research and development series no. 43. International Centre for Aquaculture and Aquatic Environments, Alabama Agricultural Experiment Station, Auburn University, Alabama.

4. DoF (Department of Fisheries), 1996. Technologies and Management for Fisheries Development. Fisheries Fortnight-compendium, Ramna, Dhaka. pp. 21-148.

5. Jha, $P$ and $S$ Barat, 2005. Effect of water exchange on water quality and the production of ornamental carp (Cyprinus carpio var. koi L.) cultured in concrete tanks manured with poultry excreta. Archives of Polish Fisheries, 13: 77-90.

6. Murthy, HS and ATR Naik, 2000. Effects of dietary protein and lipid levels on growth, survival and food conversion of Indian major carp (Catla catla). Israeli Journal of Aquaculture - Bamidgeh, 52: 70-6.

7. Priestley, SM, AE Stevenson and LG Alexander, 2005. The influence of feeding frequency on growth and body condition of the common Goldfish (Carassius auratus). The WALTHAM International Nutritional Sciences Symposia. pp 45.

8. Przybyl, A and J Mazurkiewicz, 2004. Nutritive value of cereals in feeds for common carp (Cyprinus carpio L.). Czech Journal of Animal Science, 49:307-14.

9. Prithwiraj, J, S Barat and CR Nayak, 2008. Fish production, water quality and bacteriological parameters of Koi Carp ponds under live-food and manure based management regimes. Zoological Research, 29: 165-173.

10. Raihan, $\mathrm{MH}, 2010$. Production and health status of Thai koi under monoculture farming system in Mymensingh. M.S. Thesis. Department of Aquaculture, Bangladesh Agricultural University, Mymensingh. 35p.

11. Rashid, $\mathrm{MH}, 2008$. Effect of stocking density on the growth, survival and production of mono sex GIFT tilapia (Oreochromis niloticus L.) reared in recirculatory system in cisterns. MS Thesis. Department of Aquaculture, BAU, Mymensingh. 68 pp.

12. Rema, $P$ and Gouveia, 2005. Growth and Survival of Goldfish (Carassius auratus) Larvae Reared at Different Densities. Journal of Animal and Veterinary Advances, 4: 274-275.

13. Rai, AK and JD Bista, 2000. Effect of different feed ingredients on the growth of caged common carp. Nepal Agriculture Research Journal, 60: 4 - 5 .

14. Uddin, M, 2002. Effect of addition of small fish on the pond ecology and the production in polyculture. M.S. Thesis. Department of Fisheries Management, Bangladesh Agricultural University, Mymensingh, 81pp. 